\title{
Spatial Modeling of Whreathed Hornbill (Acerosundulatus) Habitat in Mount Ungaran Central Java
}

\author{
M. Rahayuningsih, N. E. Kartijono, and E. Suharini
}

\begin{abstract}
The objective of the research was to find the suitable habitat for Whreathed Hornbill (Acerosundulatus) using GIS in Mount Ungaran. The research was carried out in five stations: Banyuwindu, Gajah Mungkur, Watu Ondo, Gunung Gentong, and Gajah Mungkur. The method of data collection consisted of spatial data and tabular data. The determining of habitat and the nest distribution were carried out using GPS (Global Positioning System) andprocessing the data was using Arc Gis and Erdas Imagine 9.1 software.The results showed that very suitable area for bird habitat in Mount Ungaranwas 2436.73 ha (13\%), whereas 985.11 ha $(51 \%)$ was considered as suitable area and 7171.37 ha or $36 \%$ as unsuitable area. The results validate the suitability of habitat for Whreathed Hornbill is $75 \%$. The accuracy value of $75 \%$ indicates that the suitability map model for Whreathed Hornbill habitat is relatively good and is acceptable.
\end{abstract}

Index Terms-Acerosundulatus, mount Ungaran, spatial modeling.

\section{INTRODUCTION}

There are three species of hornbills in Java and one them is Whreathed Hornbill (Acerosundulatus ) which can be found in Mount Ungaran [1]. Disruption of the natural habitat poses a serious threat that can disrupt the presence of birds in Mount Unggaran, such as habitat fragmentation, forest clearing for coffee or tea plantation, illegal logging, hunting and trade of birds.Fragmentation of the landscape may have severe consequences for forest biota, including loss of suitable habitat for sensitive species [1] and increasing competition from generalist species [2], all of which may ultimately result in local extinction of native forest dependent species. The analysis of population showed thatdensity value of Whreathed hornbill in Mount Ungaranwas $14.60 \mathrm{bird} / \mathrm{Km}^{2}$ [3]. In general it can be said that Mount Ungaran is a suitable habitat for Whreathed hornbill.

Mount Unggaran is one of the area that has been designated as an Important Birds Areas (IBA) in Indonesia, especially in Central Java by Bird Life of Indonesia [4]. Whreathed Hornbill that should be preserved from extinction. The main factors thatcould threaten itsexistence, if not anticipated it is estimated that the forest area as the natural habitat for the birds is getting less. One of the efforts that must be made is to identify zones of suitable habitat for the bird sustainability and also as an in-situ conservation strategy.

In addition,tothe in-situ conservation planning and wildlife management including birds, it is necessary to have complete

Manuscript received April 25, 2014; revised July 27, 2014.

M. Rahayuningsih is with Semarang State University, Indonesia (e-mail: etak_sigid@yahoo.com). data regarding the major life necessities and behavior. The necessity is the main living space of suitable habitat and availability of food, water, shelter and breeding. Good planning and management needs to be supported with accurate maps, such as administrative boundary maps, road maps, climate maps, contour maps, bird distribution maps, and a land cover classification maps. The maps can further support the efforts to manage and utilize the Mount Unggaran area.

The study of whreathed hornbill such as the individual frequency measurements and populations measurements as well as vegetation diversity in the observation stations only, not supported by habitat modeling in the region. Habitat modeling using GIS can provide data zones which are appropriate for the habitats of birds in an area as well as to determine its Home Range. Many Remote Sensing (RS) and GeographicInformation System (GIS) applications have been used to develop spatially explicit wildlife habitat map [5]. GIS technique can be used to examine factors such as the availability of food and land cover, refuge from predators, and the suitability of an area as a nesting and reproduction of animals [6]. RS and GIS also support in monitoring areas of land for their suitability to endangered species, through integration of various habitat variables of both spatial and non-spatial nature [7]. The outputs of such models quite simple, easily understandable and can be used for the assessment of environmental impacts or prioritization of conservation efforts in a timely and cost-effective manner [8], [9]. GIS modeling has been used to examine the habitat and home range of some species such as grasland birds [10], diversity of birds [11] and Muntjak [12].

The objective of this study was to find the suitable habitat for Whreathed Hornbill (Acerosundulatus) by using GIS as part of strategic in-situ conservation effort in Mount Ungaran.

\section{PROCEDURE}

The study area was inMount Ungaran Central Java with ordinate $S 7^{0} 12^{\prime} \mathrm{E} 110^{0} 20^{\prime}$ (Fig. 1). The research was conducted on May - December 2013.

The materials and equipments needed for this research are: binocular (Nikon $8 \times 30,8.3$ "CF WF), Monocular (Nikon 20 $\times$ 60), GPS (Global Positioning System) Garmyn e-trex 12 chanel, Bird Field Guide : Sumatra; Java, Bali, Kalimantan [13],tallysheet, and stationeries.

The data collection consisted of spatial data and tabular data. Spatial data included topographic maps consisting of residential maps, road maps, river map, elevation maps, slope maps and land cover derived from landsat image 2012, while the tabular data used is the distribution of Whreathed hornbill 
nest in Mount Unggaran. The process of determining habitat and nest distribution was carried out by using GPS (Global Positioning System).Processing was using Arc Gis and Erdas Imagine 9.1 software.

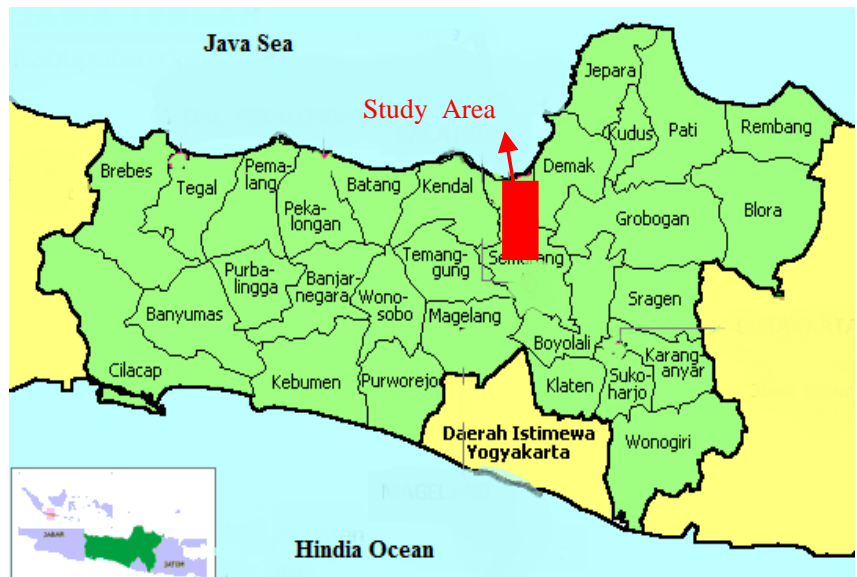

Fig. 1. Approximate of the study area (box area), between Kendal and Semarang Residence in the Central Java.

The modeling was done through spatial analysis and statistical analysis using GIS based on overlay method, class, classifying, scoring, and weighting (Table I). The ranking method with the professional judgment using for the weighting factor [14].

TABLE I: THE FACTOR AFFECTINGOF THE HABITAT OF WHRETAHED HORNBILL IN MOUNT UNGARAN

\begin{tabular}{clcc}
\hline No & \multicolumn{1}{c}{ Class } & Code & Weighed (\%) \\
\hline 1 & Land cover & $X_{1}$ & 30 \\
2 & Elevation & $X_{2}$ & 25 \\
3 & Slope & $X_{3}$ & 25 \\
4 & River distance & $X_{4}$ & 5 \\
5 & Road distance & $X_{4}$ & 5 \\
\hline
\end{tabular}

TABLE II: CLASS, CLASSIFICATION, SCORING FACTOR

\begin{tabular}{|c|c|c|c|}
\hline \multicolumn{4}{|c|}{1 Landcover Class } \\
\hline Class & Land Cover & Classification & Score \\
\hline 1 & Primary Forest & Very Suitable & 30 \\
\hline 2 & Secondary Forest & Suitable & 20 \\
\hline 3 & Plantation Area & Not Suitable & 10 \\
\hline 4 & Residence Area & Not Suitable & 10 \\
\hline \multicolumn{4}{|c|}{2 Height Class } \\
\hline Class & Height (mdpl) & Classification & Score \\
\hline 1 & $700-1600$ & Very Suitable & 20 \\
\hline 2 & $>1600$ & Not Suitable & 10 \\
\hline \multicolumn{4}{|c|}{3 Slope Class } \\
\hline Class & Slope & Classification & Score \\
\hline 1 & $50-80$ & Very Suitable & 30 \\
\hline 2 & $30-50$ & Suitable & 20 \\
\hline 3 & $<30$ & Not Suitable & 10 \\
\hline \multicolumn{4}{|c|}{4 Water resource distance class } \\
\hline Class & Distance (m) & Classification & Score \\
\hline 1 & $<500$ & Very Suitable & 20 \\
\hline 2 & $>500$ & Not Suitable & 10 \\
\hline \multicolumn{4}{|c|}{5 Road distance class } \\
\hline Class & Distance (m) & Classification & Score \\
\hline 1 & $>1000$ & Very Suitable & 20 \\
\hline 2 & $<1000$ & Not Suitable & 10 \\
\hline
\end{tabular}

Layers that have been graded and scored, superimposed using the "union" (Table II). Overlay performed to obtain the final map which is a combination of the five factors mentioned above. Overlay results were further validated by using coordinate points of Whreathed Hornbill nesting observations that have been done.

The area suitability model is composed as follows:

Total Score $=0.3 \times$ score $X_{1}+0.25 \times$ score $X_{2}+0.25 \times$ score $X_{3}+0.05 \times$ score $X_{4}+0.05 \times$ score $X_{5}$

\section{RESUlT AND DisCUSSION}

WhreathedHornbill's habitat suitability models using 5 (five) factors that may influence WhreathedHornbill habitat such as land cover, altitude, slope, the distance from the river and the distance from the road. Wildlife habitat occupied in accordance with the necessary environment to support life. A suitable habitat for a species is not necessarily appropriate for other types, because every type of wildlife requires different habitat conditions. Therefore, the determining factor for the suitability of a particular type of wildlife habitat is affected by the needs of that wildlife itself.

Layers that have been graded and scored, superimposed using the "union" and overlay performed to obtain the final map which is a combination of the five factors. Overlay results were further validated by using coordinate points of Whreathed Hornbill nesting observations that have been done. The fifth overlay layer produced WhreathedHornbill habitat suitability map (Fig. 2).

TABLE III: THE DISTRIBUTION OF WHREATHED HORNBILL SUITABILITY HABITAT IN MOUNT UNGGARAN

\begin{tabular}{clcc}
\hline No & Information & Width (Ha) & Percentage (\%) \\
\hline 1 & Very Suitable & 2436.73 & 13 \\
2 & Suitable & 9851.11 & 51 \\
3 & Not suitable & 7171.37 & 36
\end{tabular}

Suitability class is divided into three (3) classes area; they are very suitable class, suitable class and not suitable class with the details as shown in the table below (Table III). The area which is highly suitable for Whreathed Hornbill habitats in Mount Unggaran covers 2436. 73 ha (13\%), the suitable area covers 9851.11 ha $(51 \%)$ and the not suitable area covers 7171.37 ha $(36 \%)$ (Table III, Fig. 2).

To test the structured model, whether it is suitable or not in predicting habitat suitability, the final result of the model is validated by using the encounter points data of Whreathed Hornbill's nests (Table IV, Fig. 3). The results of the model validation is showed that Whreathead Hornbill's nest points is located in the very suitable area, the nest is located in the suitable area and during the studied there is no nest of Whreathed Hornbill were found in the not-suitable area.

TABLE IV: THE DiSTRIBUTION POINTSOF WHREATHED HORNBILL AGAINST THE ARRANGED SUITABILITY CLASSES

\begin{tabular}{llc}
\multicolumn{3}{c}{ THE ARRANGED SUITABILITY CLASSES } \\
\hline No & Suitability class & $\begin{array}{c}\text { The amount of nests and } \\
\text { individual }\end{array}$ \\
\hline 1 & Suitable & 2 \\
2 & Highly suitable & 6 \\
\hline
\end{tabular}




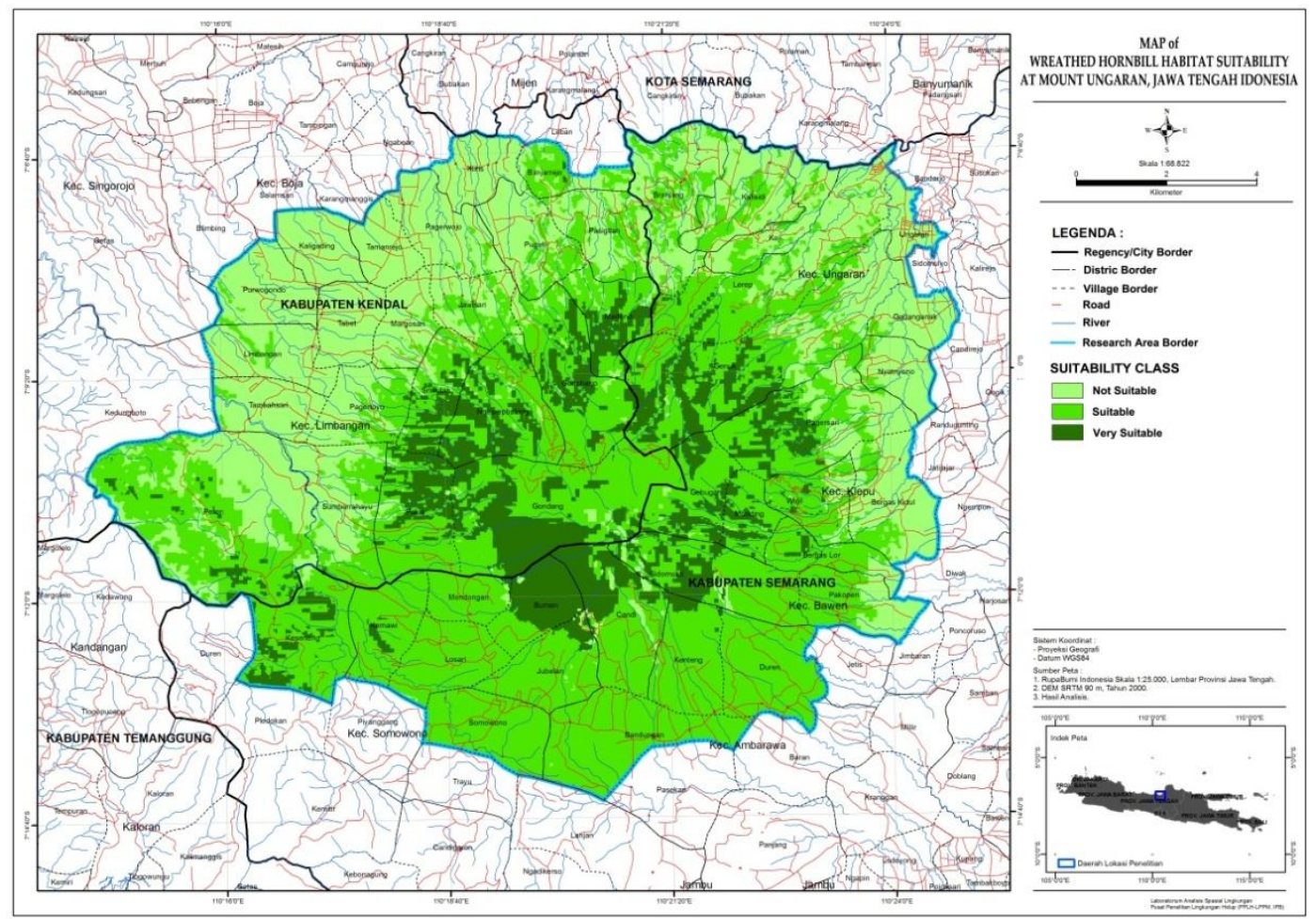

Fig. 2.Whreathed hornbill suitability habitat in Mount Ungaran.

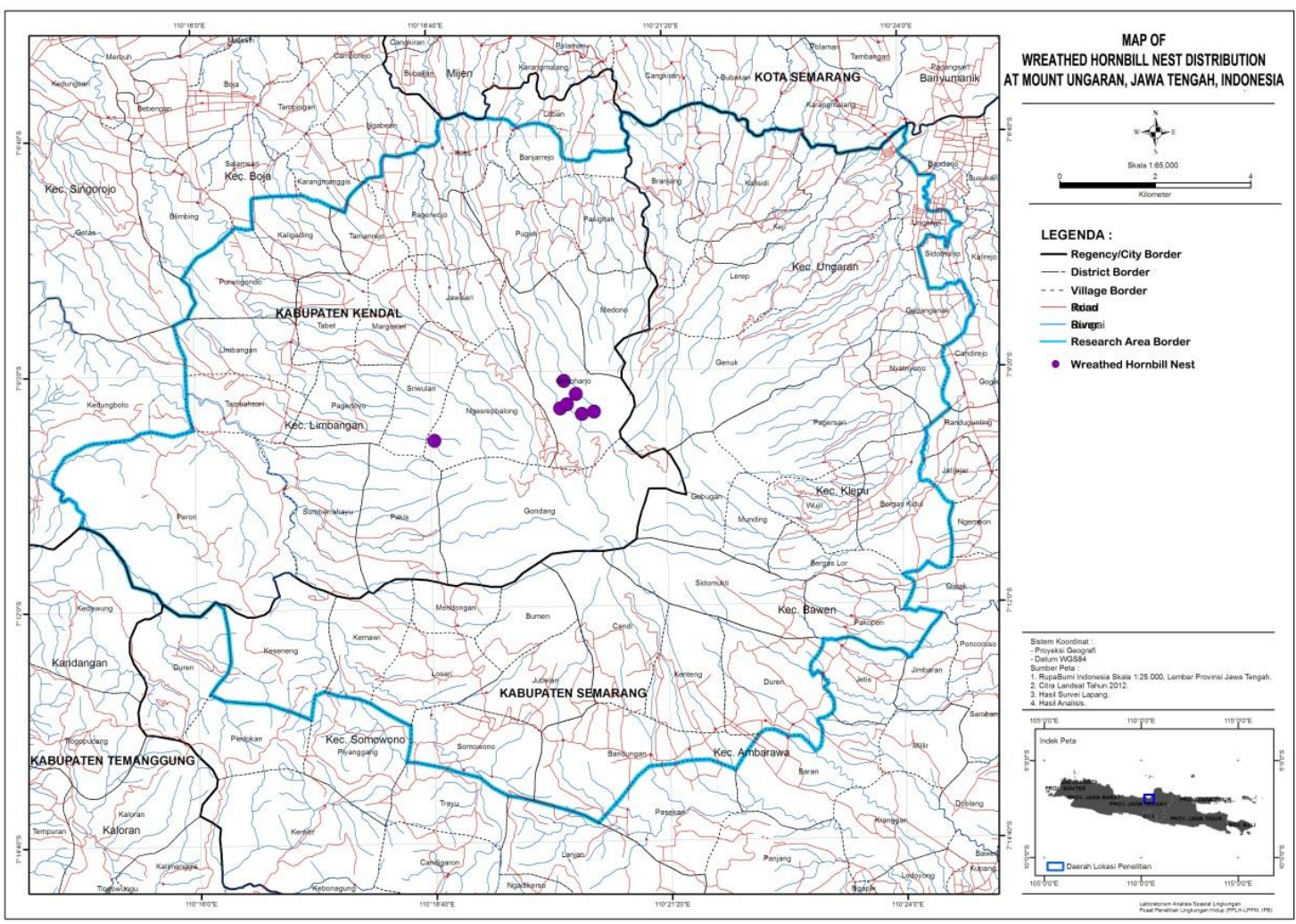

Fig. 3. Nest location of whreathed hornbill in Mount Ungaran.

The validation results on the suitability of Whreathed Hornbill habitat is $75 \%$. The accuracy value of $75 \%$ indicates that a model for Whreathed Hornbill habitat suitability maps is quite good and is acceptable $(50 \%-<85 \%)$ [14]. The modeling result shows that generally Mount Unggaran is a suitable habitat and is very suitable for the survival of Whreathed Hornbill. Most of the areas which are suitable for Whreathed Hornbill are located in Semarang Regency.

The "very suitable" area was covers 2436.73 hectares or about $13 \%$ of the total area in Mount Unggaran. While the area that belongs to the "suitable"areawas covers 9851.11 ha or about $51 \%$. Another 7171.37 ha belongs to the not suitable $\|$ area $(36 \%)$. Habitat types in this region is forest, padi fields, tea and coffe plantations, settlements, rivers, and grassland. The most important factor is the location of Whreathed Hornbill nesting habitat which are categorized as very suitable\| area are located in the forests, on the tree with the height of $>25$ meters, located at an altitude of 900-1200 meters above sea level, and the slope of $>30$. The elevation of habitat location of Whreathed Hornbill between 0-2000 
meters above sea level [15]. The loss of habitat is a serious threat for Whreathed Hornbills in Mount Unggaran. Forest as their habitat is a land ecosystem that contains natural resources dominated by trees is facing a dangerous threat. At Mount Unggaran, habitat fragmentation, forest clearing into coffee or tea plantation, as well as the existence of illegal logging is very influential in accelerating the destruction of the forest. Hornbills tend to be affected by habitat disturbance, including logging, forest fires and other habitat disturbances [15]-[17]. Fragmentation of the landscape may have severe consequences for forest biota, including loss of suitable habitat for sensitive species [18] and also increasing competition from generalist species [19]. All of which may ultimately result in local extinction of native forest dependent species [19]. Large trees is the main target by illegal loggers, meanwhile large trees are the ones that became Whreathed Hornbill's habitat. The large and higher of the tree will be attract hornbills especially for nesting [20]. Based on a review of the characteristics of the nest, some researchers explained that the kind of Whreathed hornbill nest tree has a height of over 20 meters and the diameter between $40-267 \mathrm{~cm}$ [21]. Therefore, the predicted location of the suitability class, especially the ones located on very suitable areas' should be protected and preserved.

\section{CONCLUSION}

The that belongs to the "very suitable" class covers 2436.73 hectares or about $13 \%$ of the total area in Mount Unggaran. The validation results on the suitability of WhreathedHornbill habitat is $75 \%$. The accuracy value of $75 \%$ indicates a model for Whreathed Hornbill habitat suitability maps is quite good and acceptable (50\%- < $85 \%)$.

\section{ACKNOWLEDGMENT}

Thanks to the Director General of Higher Education Indonesia Ministry of Education and Culture over research funding schemes of Higher Education Competitive Research. Thanks to the brothers of "Green Community" and "Pelatuk Bird Study Club" Department of Biological Science Semarang State University who have helped during the fieldwork, Mr. Ngadi who has become the guide and Pak Min who has provided his home as a base camp

\section{REFERENCES}

[1] M. Rahayuningsih and E. K. Nugroho, "The distribution and population of whreathed hornbill in Mount Ungaran Central Java," IJEED, vol. 5, pp. 492-495, October 2013.

[2] E. Mendoza, J. Fay, and R. Dirzo, “A quantitative analysis of forest fragmentation in Los Tuxtlas, Southeast Mexico: Patterns and implications for conservation," Revista Chilena De Historia Natura. vol. 78, pp. 451-467, September 2005.

[3] W. F. Laurance, M. Goosem, and G. W. L. Susan, "Impacts of roads and linear clearings on tropical forests," Trends in Ecology and Evolusion, vol. 24, no. 12, pp. 659-669, September 2009.

[4] W. M. Rombang and Rudyanto, "Important bird area in Java and Bali," PKA/Birdlife-International Indonesia Programme, Bogor, p. 77, 1999.

[5] C. L. Lauver, H. B. William, and L. W. Jerry, "Testing a GIS Model of Habitat Suitability for a Declining Grassland Bird," Environmental Management, vol. 30, no. 1, pp. 88-97, September 2009.

[6] T. Wang, "Habitat analysis for giant panda in Laoxiancheng nature reserve," M.S. thesis, Geo-Information Science and Earth Observation (Rural and Land Ecology). International Institute for Aerospace Surveys and Earth Sciences (ITC), 2003.
[7] F. W. Davis and Goetz, "Modeling vegetation pattern using digital terrain data," Landscape Ecology, vol. 4, no. 1, pp. 69-80, March 1990

[8] S. P. Kushwaha, A. Khan, B. Habib, A. Quadri, and A. Singh, "Evaluation of sambarand muntjac habitats using geostatistical modelling," Current Science, vol. 86, no. 10, pp. 390-1400, May 2004

[9] A. A. Zarri, A. R. Rahmani, A. Singh, and S. P. S. Kushwaha, "Habitat suitabilityassessment for the endangered Nilgiri Laughingthrush: A multiple logistic regressionapproach," Current Science, vol. 94, pp 1487-1494, June 2008.

[10] C. L. Lauver, W. H. Busby, B. William, and L. W. Jerry, "Testing a GIS model of habitat suitability for a declining grassland bird," Environmental Management, vol. 30, no. 1, pp. 88-97, July 2002.

[11] A. Hakim and N. Anand, "Bird diversity modeling using geostatistics and GIS," in Proc. 12th AGILE International Conference on Geographic Information Science, Leibniz Universität Hannover, Germany, 2009, pp. 1-20.

[12] E. Ikwal, T. Hussain, and T. Mary, "Modelling of habitat suitability index for Muntjac (Muntiacus muntjak) using remote sensing, GIS and multiple logistic regression," Journal of Settlements and Spatial Planning, vol. 3, no. 2, pp. 93-102, 2012.

[13] J. MacKinnon et al., Bird in Sumatera, Jawa, Bali dan Kalimantan (Include Sabah, Serawak, dan Brunei Darussalam), Jakarta: Puslitbang - Biologi, 2010, p. 234.

[14] I. N. S. Jaya, Citra Digital Analysis: Perspektif Penginderaan Jauh untuk Pengelolaan Sumberdaya Alam, Institut Pertanian Bogor, 2009.

[15] M. F. Kinnaird and T. G. O'Brien, "Ecological effects of wild fire on lowland rainforest in Sumatra," Conserv. Biol., vol. 12, pp. 954-956, October 1998.

[16] A. Johns, "Ecological effects of selective logging in a West Malaysian rain forests," PhD dissertation, Cambridge University, 1983.

[17] A. J. Cahill and J. S. Walker, "The effects of forest fire on the nesting success of the Red-knobbed Hornbill Aceroscassidix," Bird Conserv. Internat, vol. 10, pp. 109-114, June 2000.

[18] E. Mendoza, J. Fay, and R. A. Dirzo, "A quantitative analysis of forest fragmentation in Los Tuxtlas, Southeast Mexico: patterns and implications for conservation," Revista Chilena De Historia Natural, vol. 78, pp. 451-467, September 2005.

[19] W. F. Laurance, M. Goosem, and S. G. W. Laurance, "Impacts of roads and linear clearings on tropical forests," Trends in Ecologyand Evolusion, vol. 24, no. 12, pp. 659-669, December 2009.

[20] P. Poonswad, "Nest site characteristics of four sympatric species of hornbills in KhaoYai National Park, Thailand," IBIS, vol. 137, pp 183-191, April 1995

[21] A. Marty, "Review: Breeding ecology and nest site characteristics of hornbills insituand ex-situ," Harapan Raint Foreat, pp. 9-12, 2008.

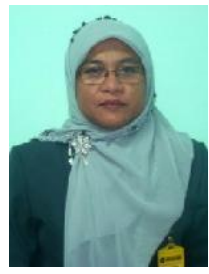

Margareta Rahayuningsih was born in Semarang Central Java Indonesia on January 22, 1970. She received the $\mathrm{PhD}$ degree in the Department of Natural Resources Conservation and Ecoturism-Forest Faculty, Bogor Agriculture Institute. She was a lecturer in the Department of Biology-Mathematic and Natural Science from 2011 to 2013, the director of "Omah Keboen" Bioeduenterpreunership Programme in the Science Faculty, Semarang State University (SSU). She was also the head of Conservation Agency Semarang State University from 2011 to 2013

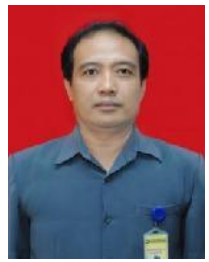

Nugroho Edi Kartijono was born in Ponorogo, East Java Indonesia on December 13, 1961. He received the master degree of science from Biology Faculty of Gadjah Mada University. He was a lecturer in the Department of Biology-Mathematic and Natural Science Faculty, Semarang State University (SSU). He is also the director of Eduwisata in SSU.

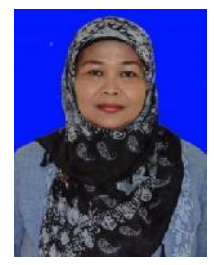

Erni Suharini was born in Semarang on November 6 , 1962. She received the master degree of science from Physical og Geographic of Gadjah Mada University. She was a lecturer in the Department of Geographic Social Science Faculty, Semarang State University (SSU). She is also the vice dean of administration and financial in Social Science Faculty, Semarang State University (SSU). 